УДК 351.77:614.2

DOI: $10.34132 /$ pard2020.07.04

\title{
ЗАСТОСУВАННЯ ДІАЛОГІЧНОЇ МОДЕЛІ ЗМІН У ПРОЦЕСІ РЕФОРМУВАННЯ СИСТЕМИ ОХОРОНИ ЗДОРОВ' Я В УКРАЇНІ НА ПЕРВИННОМУ РІВНІ
}

Дзвінчук Д.І., д-р філос. наук, професор, Івано-Франківський національний технічний університет нафти і газу, м. Івано-Франківськ, Україна

Баран М.П., канд. наук 3 держ. упр., доцент, Івано-Франківський національний технічний університет нафти і газу, м. Івано-Франківськ, Україна

У публікаиії констатовано підстави проведення реформування охорони здоров'я в Украӥні зважаючи на кризову медико-демографічну ситуацію та потребу збереження й покращення здоров'я не тільки як факту відсутності захворювань чи фізичних дефектів, а й як факту повного фізичного, психічного та соціального благополуччя населення.

Проаналізовано ключові кроки, щุо були зроблені у контексті впровадження реформи системи охорони на первинному рівні здоров'я з позиції діалогічної моделі змін, яка передбачає орієнтоване на результат структуроване планування та проведення діалогу зацікавлених сторін протягом чотирьох етапів: вивчення та залучення; розбудова та формалізачія; впровадження та оцінка; подальший розвиток, відтворення / інституалізація. Кожен із чотирьох етапів діалогічної моделі змін включає кроки, яких варто дотримуватися, щзоб будь-яка інічіатива досягла поставленої мети. Діалогічна модель змін пояснює, щуо потрібно врахувати для однозначного сприяння діалогу та орієнтації на результат.

Доведено, щзо результат реформи системи охорони здоров'я, як і будь-якої іншої, залежсить від досвіду управління прочесами та змінами, трунтовного розуміння конщепџіï змін, вміння всіма заці- 
кавленими суб'єктами процесу реформування аналізувати та оперувати інформачією.

Підсумовуючи позитивні досягнення реформи системи охорони здоров'я - забезпечення державних гарантій надання медичних послуг відповідно до видів медичної допомоги; розвиток ефективної та доступної мережі закладів; безперервне покращення якості медичної допомоги; впровадження електронної системи охорони здоров'я; забезпечення пачієнтів лікарськими засобами тощо, акиентовано на потребі комплексного застосування організаційного-управлінського, інформаційно-комунікаційного, фінансово-економічного, нормативно-правового та інших механізмів для ефективного впровадження реформи системи охорони здоров'я через призму діалогічної моделі змін.

Ключові слова: громадськість; реформування, система охорони здоров'я, первинний рівень медичної допомоги, діалогічна модель змін.

Постановка проблеми у загальному вигляді. Відповідно до Конституції України кожен має право на охорону здоров'я, медичну допомогу та медичне страхування. Держава створює умови для ефективного і доступного для всіх громадян медичного обслуговування. У державних і комунальних закладах охорони здоров'я медична допомога надається безоплатно; існуюча мережа таких закладів не може бути скорочена. Держава сприяє розвиткові лікувальних закладів усіх форм власності [15]. Та чи виконувалась ця стаття Конституції України?

Україна вступила у XXI ст. $з$ одними з найгірших у Свропі показників життєдіяльності й тягарем багатьох соціально-економічних та демографічних проблем [14]. Роки незалежності нашої держави пов'язані із кардинальні змінами. Реформи торкнулися всіх секторів соціально-економічної системи - це реформи у секторі міноброни, нацполіції, нафтогазової промисловості, банківської, виборчої систем, реформа у сфері надання адміністративних послуг, створенні відкритих баз даних/реєстрів, системи електронних держзакупівель Prozorro, реформа систем державного управління, освіти та охорони здоров’я, децентралізація та інші [35]. 
Незважаючи на значні позитивні зрушення та досягнення, в Україні продовжують існувати проблеми, які були актуальними й десятиліття тому. Політичне гальмування економічних та соціальних реформ, низький рівень заробітної плати та пенсій, недостатня правова культура та соціальна захищеність громадян, низка проблем пов'язана 3 молоддю, особливо з молодими сім'ями, які не завжди можуть отримати роботу і заробітну плату, яка дозволить їм самореалізуватися в країні, еміграція значної частини працездатного населення України, соціально-політичне напруження, яке посилюється військовими діями на Сході країни безумовно впливає на демографічну ситуацію і стан здоров'я населення.

За словами екс-виконувачки обов'язків Міністра охорони здоров’я Уляни Супрун «з 1930-х років тривалість життя в Україні залишається на тому самому рівні, а за останні 25 років рівень смертності зріс. Якщо порівнювати з іншими країнами, на Заході за останні 10 років тривалість життя подовжилася на 10 років, а рівень смертності знизився до рівня, що становить майже половину сьогоднішнього показника в Україні. Простіше кажучи - українська нація вимирає, що робить наше виживання питанням національної безпеки» [39]. Відтак закономірною та давноочікуваною реформою в Україні стала реформа системи охорони здоров'я.

Аналіз останніх досліджень і публікацій. Сьогодні низка науковців працює над дослідженням реформування системи охорони здоров'я. У публікаціях в основному робиться акцент на необхідності реформування системи охорони здоров'я України, вивченню досвіду функціонування різних систем охорони здоров'я у світі та можливостей адаптування кращих практик для побудови ефективної системи охорони здоров’я в Україні, модернізації функцій місцевого самоврядування в умовах реформування системи охорони здоров'я тощо. Проте публікацій, спрямованих на аналіз дієвості впровадження медичної реформи у державі недостатньо.

Формування цілей статті (постановка завдання). Полягає у аналізі результативності реформування системи охорони здоров'я в Україні на первинному рівні через призму діалогічної моделі змін. 
Виклад основного матеріалу дослідження. Проаналізуємо ключові кроки, які були зроблені у контексті впровадження реформи системи охорони здоров'я з позиції діалогічної моделі змін [10], яка передбачає орієнтоване на результат структуроване планування та проведення діалогу зацікавлених сторін протягом чотирьох етапів: вивчення та залучення; розбудова та формалізація; впровадження та оцінка; подальший розвиток, відтворення/інституалізація (рис. 1) [10].

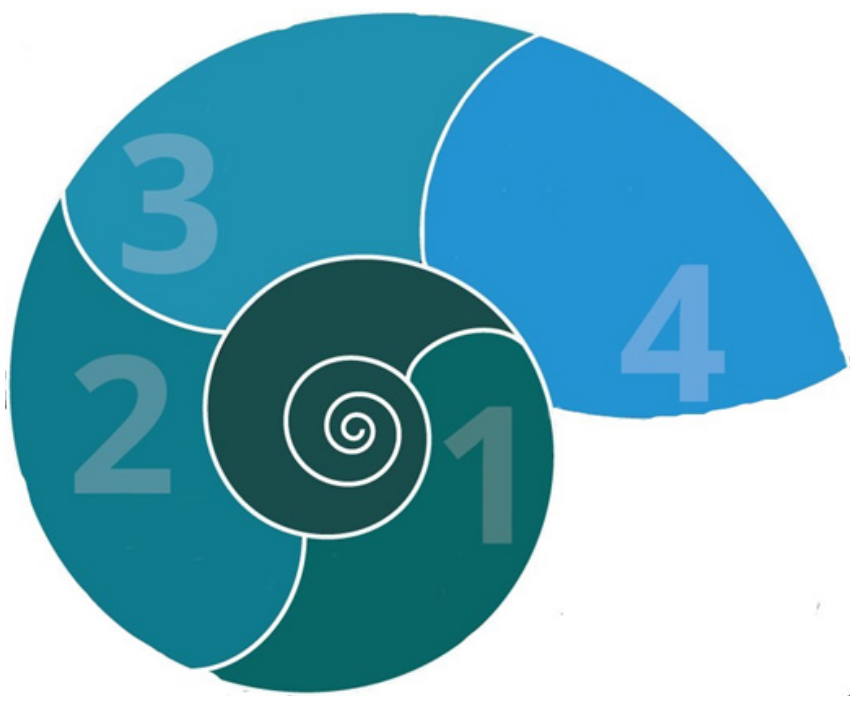

Рис.1 - Діалогічна модель змін

Модель пояснює, що потрібно врахувати для однозначного сприяння діалогу та орієнтації на результат. Аксіомою є факт, що результат реформи системи охорони здоров'я, як і будь-якої іншої, залежить від досвіду управління процесами та змінами, грунтовного розуміння концепції змін, вміння всіма зацікавленими суб' єктами процесу реформування аналізувати та оперувати інформацією.

Кожен із чотирьох етапів діалогічної моделі змін включає кроки, яких варто дотримуватися, щоб будь-яка ініціатива досягла поставленої мети. Перший етап «вивчення та залучення» вважатиметься 
завершеним й уможливить перехід та досягнення результатів на наступному етапі у разі проходження таких кроків: створення резонансу, розуміння контексту, побудова команди змін.

Аналізуючи резонанс у впровадженні реформи системи охорони здоров'я варто акцентувати увагу на ситуації із станом здоров'я українців. Зважаючи на кризову медико-демографічну ситуацію в Україні одним з найважливіших пріоритетів нації має стати збереження та покращення здоров'я як не тільки факту відсутності захворювань чи фізичних дефектів, а як стану повного «фізичного, психічного та соціального благополуччя» [5] населення.

Зміст публікацій $[3,4,11,16,36,40]$ та інших красномовно засвідчує факт взаємозалежності скорочення чисельності населення України із системою охорони здоров'я. До сьогодні коефіцієнт природного скорочення населення в Україні залишається найвищим серед європейських країн.

Не менш значущими чинниками негативних демографічних тенденцій в Україні є погіршення стану здоров’я населення, низька тривалість життя, високий рівень смертності, особливо серед чоловіків працездатного віку [3]. Як стверджує І. Ціборовський, посилаючись на власні дослідження та дослідження Л.Чепелевської, О.Голяченка - «Коефіцієнти смертності населення, особливо за причинами смерті, $є$ не тільки демографічними показниками, але й показниками захворюваності, які характеризують не лише соціально-економічну ситуацію в країні, але й діяльність системи охорони здоров'я» [41].

Протягом часу незалежності держави у низці наукових праць констатовано недосконалість існуючої системи охорони здоров'я [2, $8,18]$ та ін. В. Костюк справедливо констатує, що нині в Україні станом охорони здоров'я незадоволені всі: і громадяни, і медичні працівники, і уряд, і Верховна Рада. Українська система охорони здоров'я нездатна повністю задовольнити потреби населення в медичній допомозі, забезпечити іiі доступність і належну якість, необхідний рівень профілактики захворюваності, зниження смертності, збільшення тривалості життя населення. Медична реформа не лише назріла, а й певним чином перезріла. Реалізація права людини на 
якісні медичні послуги зумовлює спрямування політики держави в Україні на реформування чинної системи охорони здоров'я та створення ефективної національної моделі [17].

Як бачимо, передумови для створення масштабного резонансу щодо важливості та терміновості системи охорони здоров'я в Україні накопичувалися десятиліттями. Відтак, 2016 р. став для системи охорони здоров'я стартом змін, які починала втілювати команда управлінців під керівництвом в.о. міністра Уляни Супрун. Схваленню Концепції реформи фінансування системи охорони здоров'я [30], яка мала на меті створення та запровадження нової моделі фінансування, що передбачала чіткі та прозорі гарантії держави щодо обсягу безоплатної медичної допомоги, кращий фінансовий захист громадян у випадку хвороби, ефективний та справедливий розподіл публічних коштів та скорочення неформальних платежів, створення стимулів до поліпшення якості надання медичної допомоги населенню державними і комунальними закладами охорони здоров'я, як і прийняттю інших нормативно-правових актів чи впровадження кроків реформи передувало громадське обговорення - що засвідчує прозорість впровадження реформи та підсилює резонанс здійснення кожного кроку на шляху до досягнення результатів, розуміння контексту реформи та формування команди змін.

Так, аналіз сайту Міністерства охорони здоров’я України (даліMO3) підтверджує, що команда MO3 інформувала українців, партнерів та світову спільноту про зміни, які чекають систему охорони здоров'я України $[22,24,28,31,34,42]$ та ін. На нашу думку, саме відмінно налагоджена комунікація, дала змогу сформувати прихильників реформи в регіонах та охопити знаннями про основні завдання реформи якнайбільшу частину працівників галузі. Наперед зауважимо, що чіткість формулювання завдань та виваженість кроків з їх здійснення перевершила сподівання самих реформаторів більше як у 2 рази (планувалось 25-30\% підписаних декларацій 3 лікарями первинної медичної допомоги [12], а станом на 31.12.2019 було підписано 69\% [37]).

Підсумовуючи дієвість кроків із першого етапу діалогічної моделі змін «впровадження та залучення» констатуємо потребу укра- 
їнського суспільства до руйнування системи охорони здоров'я Семашка, за якої бюджетні кошти використовувалися на утримання медичної інфраструктури, та створення нової моделі, яка буде побудована на сучасних досягненнях і враховуватиме позитивний досвід організації охорони здоров'я світового співтовариства. Така модель в Україні побудована за принципом «гроші ідуть за пацієнтом».

Розуміння контексту реформи було чітко визначено, що й зумовило іiі позитивний старт та просування [23]. Щоб заклади охорони здоров'я (3О3) отримали фінансування за новим принципом їм потрібно було: провести автономізацію, забезпечити комп'ютеризацію та належне програмне забезпечення для використання e-Health, отримати ЕЦП 303 та лікарів ПМД, привести 303 у відповідність до табелів матеріально-технічного оснащення, укласти декларації про вибір лікаря ПМД, укласти договір з НСЗУ [13]. Для розуміння контексту було створено низку інформаційних платформ [20], Адміністратор Центральної бази даних eHealth України [1], Децентралізація. Сектор медицина [9] та ін.

Неоціненною підтримкою команд реформаторів стала допомога міжнародних проектів та програм. Так, проект «Реформа ВІЛ-послуг у дії», який виконуються компанією Deloitte Consulting LLP та фінансується за кошти Агенства США з міжнародного розвитку (USAID) надавав підтримку у реформуванні системи фінансування охорони здоров’я. Одним з напрямків технічної допомоги Проекту була підтримка Міністерства охорони здоров’я (MO3) та окремих обласних / місцевих органів влади у розробці і впровадженні системи оплати праці за результатами виконаної роботи, з урахуванням принципу «гроші ходять за пацієнтом». Одним із завдань - надання технічної допомоги закладам первинної медико-санітарної допомоги (ПМД) для оперативного управління в умовах застосування капітаційної моделі [32]. Завдяки роботі Програми «U-LEAD з Свропою», яка підтримує секторальну децентралізацію у сферах охорони здоров'я, вдалося стати рупором реформ на місцевому рівні - рівні об'єднаних територіальних громад, міст та районів. Інформаційна, консультативна та навчальна робота проводилася командами радників регіональних Центрів розвитку місцевого самоврядування та 
командами довго - та короткотривалих експертів [33]. До популяризації реформи долучилася низка громадських організацій, метою діяльності яких є підвищення якості надання медичної допомоги.

Підсумком першого етапу діалогічної моделі впровадження реформи системи охорони здоров'я стали: консолідація зусиль ключових суб'єктів - команди МО3, глави держави, Уряду, депутатського корпусу, активної громадськості, експертного середовища; усвідомлення передумов для реформи; врахування кращих сучасних практик та досвіду трансформації систем охорони здоров'я у світі, зокрема у Центральній та Східній Свропі; оцінка ризиків та ресурсів.

Зазначені досягнення першого етапу, дозволили реформі перейти на другий етап «розбудова та формалізація», який включає такі кроки: пояснення мети та ресурсів, планування спільних майбутніх дій, консолідування угод та побудова структури.

Основними досягненнями на цьому етапі було прийняття необхідних для впровадження реформи нормативно-правових актів [27]. Основними серед яких є Закони України «Про внесення змін до деяких законодавчих актів України щодо удосконалення законодавства 3 питань діяльності закладів охорони здоров’я» (№2002-VIII від 06.04.2017) відомий як закон про автономізацію, «Про державні фінансові гарантії надання медичних послуг та лікарських засобів» (№ 2168-VIII від 19.10.2017), «Про підвищення доступності та якості медичного обслуговування у сільській місцевості» (2206-VIII від 14.11.2017). Міністерство охорони здоров'я України систематично надавало роз'яснення, щодо автономізації, іiі переваги. Розгорнуті відповіді на питання про автономізацію можна було знайти в офіційних методичних рекомендаціях, які уможливили безперешкодний перехід закладів охорони здоров'я з бюджетних установ до діяльності як комунальні некомерційні підприємства [19].

Проривом у впровадженні реформи стало затвердження положення про Національну службу здоров'я України (НСЗУ), проведення конкурсу на призначення Голови НСЗУ та у найкоротші терміни формування штату та запуск функціонування служби. НСЗУ є центральним органом виконавчої влади, який реалізує державну політику у сфері державних фінансових гарантій медичного обслуго- 
вування населення. Діяльність НСЗУ спрямовується і координується Кабінетом Міністрів України через Міністра охорони здоров’я.

Основні завдання НСЗУ:

- реалізація державної політики у сфері державних фінансових гарантій медичного обслуговування населення за програмою державних гарантій медичного обслуговування населення (програма медичних гарантій);

- виконання функцій замовника медичних послуг та лікарських засобів за програмою медичних гарантій;

- внесення на розгляд Міністра охорони здоров'я пропозицій щодо забезпечення формування державної політики у сфері державних фінансових гарантій медичного обслуговування населення [25].

На другому етапі «розбудова та формалізація» активно продовжує працювати експертне середовище на місцях, даючи поштовх до зміни свідомості ключових важелів реформи - представників органів місцевого самоврядування, головних лікарів та медичного персоналу.

Аналіз третього етапу діалогічної моделі змін «впровадження та оцінка», який включає такі кроки: забезпечення прозорості та комунікації, одержання результатів та святкування успіхів, запровадження механізмів навчання та моніторингу довів системність та послідовність змін, здійснюваних командою під керівництвом Уляни Супрун та у співпраці з командою Олега Петренка, голови Національної служби здоров'я України.

Варто зазначити, що офіційні сайти МО3 [21], НС3У [26] є інформативними для різних зацікавлених читачів, як для медичних працівників, так і для пацієнтів, що свідчить про прозорість ведення діяльності та провадження реформи і бажання донести інформацію до широкого кола читачів. Вчасне інформування про завдання, стан та перспективи реформи системи охорони здоров'я України дали змогу уникнути низки помилок. Додатково МО3 публікувала національну медичну стіннівку - Дайджест змін у системі охорони здоров’я. «Ми починаємо випускати національну медичну стіннівку для медиків. Будемо розповідати про зміни в системі охорони здоров'я, про важливий досвід громад та окремих закладів. I, звичай- 
но, відповідати на ваші запитання. Просимо вас роздрукувати цю стіннівку на звичайному принтері і повісити там, де у вас зазвичай збираються лікарі. Доступ до інформації про зміни повинен мати кожен медик. Стіннівка має висіти в кожній ординаторській, скрізь, де збираються лікарі», - коментувала Уляна Супрун [6]. Сьогодні, на жаль, на сайті MO3 не опубліковано нових номерів дайджестів, останній датовано вереснем 2019 року [6]. Принагідно зазначимо, що інформація змісту дайджестів $є$ корисною та інформативною не тільки для медичних працівників, а й для пацієнтів та інших суб'єктів, які зацікавлені в успіху реформи.

Важливим продовженням першого етапу діалогічної моделі змін стало ведення НСЗУ активної інформаційно-комунікаційної кампанії не тільки на офіційному вебсайті, а й у соцмережі «Facebook» [38]. Згодом НСЗУ було створено ще й інформаційно-довідкову службу, сконтактувати із якою можна протягом 24 годин 7 днів на тиждень безкоштовно за коротким номером 16-77. Пацієнти, медичний персонал, керівники медзакладів, а також представники місцевої влади отримали можливість дізнатися все про зміни системи фінансування на первинній ланці. Дзвінки безкоштовні із стаціонарних та всіх мобільних операторів України [29].

Поширення кращих практик - бенчмаркінг - відіграло значну роль у досягненні мети реформування первинної ланки медичної допомоги. Платформи, на якій популяризовано досягнення автономізованих закладів охорони здоров’я є НСЗУ [38], «Децентралізація. Сектор медицина» [9] та ін. Такий обмін досвідом дозволив уникнути низки проблемних моментів, з якими стикалися першопрохідці в процесі автономізації, підключення до медичних інформаційних систем, закупівля матеріально-технічного оснащення комунальних некомерційних підприємств, написанні статутів, підписанні договорів із НСЗУ, прийнятті колективних договорів, усвідомленні зміни механізму фінансування та складанні фінансових планів тощо.

Створення надійної команди змін дозволило отримати позитивні результати реформи у найкоротші терміни. У звітах НСЗУ прослідковується позитивна динаміка в укладенні договорів уже після першої хвилі. 97\% комунальних закладів охорони здоров’я на 
первинці перейшли на нову модель фінансування на початку 2019 року. За даними звіту Національної служби здоров'я України на 31.12.2019 р. підписано з НСЗУ 1466 договорів, з яких 1050 - комунальними закладами; 168 - приватними (без ФОП); 248 - ФОП [44].

Варто зазначити, що переваги реформи відчули ФОП та приватні заклади, підписання договорів з НСЗУ яких активізувалося саме під час другої та третьої хвиль. Така активність, на нашу думку, зумовлена систематичним інформуванням НСЗУ щодо виплат, які здійснені медзакладам, що уклали договорі з НСЗУ. Найбільш компетентні та пацієнтоорієнтовані фахівці первинки почали заробляти в 2-4 рази більше, ніж раніше. I не тільки лікарі, але й медсестри та інші представники медичного персоналу. Гроші пішли за пацієнтом. Наприкінці 2018-го НСЗУ мала 623 заклади-партнери, яким за весь 2018 рік перерахували 3,5 млрд гривень [43].

3 метою забезпечення якості надання медичних послуг проводився моніторинг. НСЗУ, згідно з Положення про НСЗУ і постанови Кабінету міністрів України має право перевіряти лікаря-ФОП на відповідність вимог до надавача послуг та проводити моніторинг за місцем надавача послуг. У п .19 «Надавач зобов’язується» договору з НСЗУ визначено основні пункти, відповідно до яких може здійснюватися моніторинг виконання умов договору [7].

Підставами моніторингу НСЗУ якості надання послуг можуть бути скарга від пацієнта, яку він/вона може подати за коротким номером 16-77 або поштою, інформація про факти вимоги грошей за послуги, які включені в програму медичних гарантій, про порушення прав пацієнта на захист персональних даних тощо. Також НСЗУ може проводити моніторинг виконання умов договору шляхом звірки повноти та достовірності інформації, внесеної до звіту про медичні послуги за договором, $з$ інформацією, що міститься в системі, медичною документацією та іншими даними, що свідчать про надання послуг згідно з договором. Систематичний моніторинг дозволяє вчасно виявити та усунути порушення, а також є важливим інструментом унеможливлення дискредитування реформи.

Четвертий етап «подальший розвиток, відтворення/інституалізація», передбачаючи такі кроки: побудова команди змін для на- 
ступного рівня, створення структури управління, забезпечення менеджменту та системи навчання, був забезпечений командою змін, сформованою на першому етапі діалогічної моделі змін. Така команда включала великі суспільні групи (рис. 2).
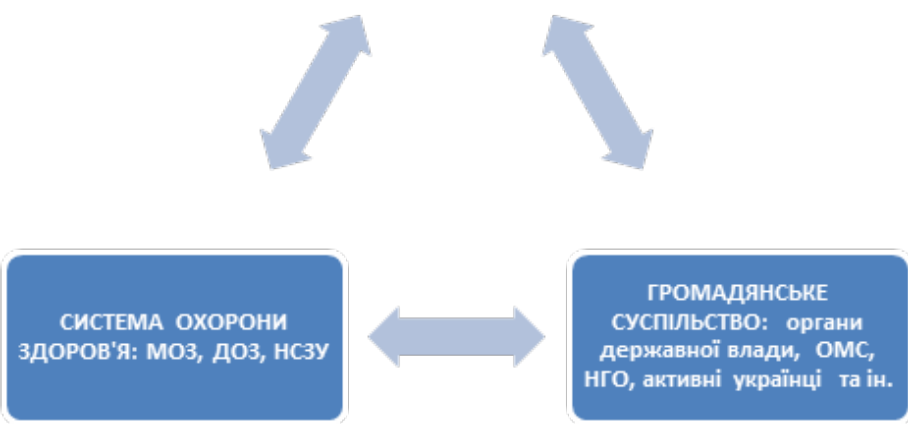

Рис.2 - Основні суб'єкти діалогічної моделі змін

Кожна із цих груп має власні завдання, мотивацію, керується власними принципами, по-різному може відчувати ризики від провадження змін. Проте, чітке дотримання кожного із кроків на попередніх етапах діалогічної моделі змін, вирішення проблемних моментів, дотримання правил ведення діалогу уможливили перехід на четвертий етап діалогічної моделі змін та заклало початок реформи системи охорони здоров'я на наступних рівнях.

Висновки з дослідження і перспективи подальших розвідок у цьому напрямі. Трансформація первинної ланки медичної допомоги - це лише перший крок реформи системи охорони здоров'я. Програма медичних гарантій повинна запрацювати в повному обсязі у 2020 році. Вона має включати в себе основні види медичної допомоги та напрямки роботи: первинна медична допомога, екстре- 
на медична допомога, амбулаторно-поліклінічна та стаціонарна медична допомога, паліативна медична допомога, медична реабілітація, лікарські засоби, які підлягають реімбурсації. Ефективність цих напрямів реформи, яку сьогодні втілює нова команда реформаторів під керівництвом Міністра охорони здоров’я України Зоряни Скалецької, щоразу залежатиме від якості виконання завдань кожного 3 етапів діалогічної моделі на новому витку змін.

Підсумовуючи позитивні досягнення реформи системи охорони здоров'я - забезпечення державних гарантій надання медичних послуг відповідно до видів медичної допомоги; розвиток ефективної та доступної мережі закладів; безперервне покращення якості медичної допомоги; впровадження електронної системи охорони здоров'я; забезпечення пацієнтів лікарськими засобами тощо, звернемо увагу на кілька завдань, вирішення яких покращить результативність та ефективність впровадження наступних напрямів реформування системи охорони здоров'я та не дискредитує досягнення реформи первинної медичної допомоги. Вирішення цих завдань, на нашу думку, потребує врегулювання через комплексне застосування організаційного-управлінського, інформаційно-комунікаційного, фінансово-економічного, нормативно-правового та інших механізмів управління реформою системи охорони здоров'я через призму діалогічної моделі змін. Варто врахувати, що під час першого етапу реформи активніше варто було б попрацювати над вирішенням таких завдань:

- організація та проведення системних навчань для керівників, бухгалтерів та інших працівників КНП з питань, пов'язаних із зміною форми господарювання - 3 бюджетних установ на комунальні некомерційні підприємства (КНП). Головним лікарям необхідні системні знання з управління КНП. Необхідно завчасно проводити більше навчань, тренінгів, надавати інструкції, методичні рекомендації тощо. Необхідне розроблення типових документів - колективних договорів, проектів обов'язкових документів, які мають приймати керівники КНП. Такі напрацювання допомогли б на початкових етапах реорганізації закладів. Особливо це важливо перед реформуванням спеціалізованої медичної допомоги. Зміна принципу фінан- 
сування вимагає нових знань у бухгалтерів, які звикли працювати 3 кошторисами, а повинні працювати з фінансовими планами;

- важливим для досягнення результатів реформи є забезпечення інформацією, доступною для сприйняття різною аудиторією, про цілі, кроки та програми реформування; проведення активної комунікаційної кампанії у місцевих 3МІ з залученням місцевих лідерів реформи, обов'язково керівників місцевих органів влади. Зауважимо, що лідерами реформи є ті області України, у яких наявна тісна продуктивна співпраця влади та працівників сектору охорони здоров’я. Забезпечення належної комунікації - є надважливим завданням у процесі впровадження та управління змінами, яка не тільки дозволить впровадити зміни більш «м’яко», а й дасть можливість вирішити ризики з найменшими втратами.

\section{Стаття надійшла до редакції: 04.01.20}

\section{APPLICATION OF THE DIALOGICAL MODEL OF CHANGES IN THE PROCESS OF REFORMING THE HEALTH SYSTEM IN UKRAINE AT THE PRIMARY LEVEL}

Dmytro Dzvinchuk, Doctor of Philosophical Sciences, Professor, Ivano-Frankivsk National Technical University of Oil and Gas, IvanoFrankivsk, Ukraine

Mariya Baran, $\mathrm{PhD}$ in Public Administration, Associate Professor, Ivano-Frankivsk National Technical University of Oil and Gas, IvanoFrankivsk, Ukraine

The publication states the grounds for health care reform in Ukraine, taking into account the medical and demographic crisis and the need to preserve and improve health, not only as a result of the absence of diseases or physical defects, but also as a fact of complete physical, mental and social well-being of the population.

The key steps that have been taken in the context of the implementation of primary health care reform from a dialogical model of change 
are analyzed, which envisages result-oriented structured planning and stakeholder dialogue over four stages: study and engagement; development and formalization; implementation and evaluation; further development, reproduction / institutionalization. Each of the four stages of a dialogical model of change includes steps that must be followed in order for any initiative to achieve its goal. The dialogical model of change explains what needs to be taken into account in order to facilitate dialogue and result orientation.

It has been proven that the outcome of health care reform, like any other, depends on the experience of managing processes and change, a thorough understanding of the concept of change, the ability of all stakeholders in the reform process to analyze and manage information.

Summarizing the positive achievements of the health care reform - providing state guarantees for the provision of health services in accordance with the types of health care; developing an efficient and accessible network of institutions; continuous improvement of the quality of medical care; implementation of an electronic health system; providing patients with medicines and the like, emphasized on the need for comprehensive application of organizational-managerial, information-communication, financial-economic, regulatory and other mechanisms to effectively implement health care reform through the lens of a dialogical model of change.

Keywords: public; reform, the health care system, the primary level of care, the dialogical model of change.

\section{Received: 04.01.20}

\section{References}

1. Administrator Tsentralnoi bazy danykh eHealth Ukrainy ehealth.gov.ua Retrieved from https://ehealth.gov.ua/

2. Bykhovchenko V.P. Ivaniuk O.V Horodnycha Yu.V Stan medychnoho strakhuvannia v Ukraini ta yoho priorytetni napriamy. Hlobalni ta natsionalni problemy ekonomiky. 2016. Vyp.10. S. 733-736. global-national.in.ua Retrieved from http://global-national.in.ua/archive/10-2016/153.pdf 
3. Chepelevska L.A., Rudnytskyi O.P., Dziuba O.M. Problemy demohrafichnoi kryzy v Ukraini: rehionalnyi aspekt. Ukraina. Zdorovia natsii. 2014. № 4. S. 5-9. irbis-nbuv.gov.ua Retrieved from http://irbis-nbuv. gov.ua/cgi-bin/irbis_nbuv/cgiirbis_64.exe?C21COM=2\&I21DBN=UJRN\& $\mathrm{P} 21 \mathrm{DBN}=\mathrm{UJRN} \& \mathrm{IMAGE}$ FILE_DOWNLOAD $=1 \&$ Image_file_name $=\mathrm{PDF} /$ Uzn_2014_4_3.pdf

4. Chepelevska L.A., Yashchenko Yu.B. Dynamika smertnosti naselennia Ukrainy na suchasnomu etapi: rehionalnyi aspekt. Ukraina. zdorovia natsii. 2013. № 2 (26). S.30-34 www.irbis-nbuv.gov.ua Retrieved from http://www. irbis-nbuv.gov.ua/cgi-bin/irbis_nbuv/ cgiirbis_64.exe?C21COM=2\&I21DBN $=U J R N \& P 21 D B N=U J R N \& I M A G E \_F I L E \_D O W N L O A D=1 \& I m a g e$ file name $=$ PDF/Uzn_2013_2_6.pdf

5. Constitution of the world health organization. who.int Retrieved from https://www.who.int/governance/eb/who_constitution_en.pdf

6. Daidzhest zmin u systemi okhorony zdorovia moz.gov.ua Retrieved from https://moz.gov.ua/dajdzhest-zmin-u-sistemi-ohoroni-zdorov\%e2\%80\%99ja

7. Deiaki pytannia shchodo dohovoriv pro medychne obsluhovuvannia naselennia za prohramoiu medychnykh harantii: Postanova KMU vidvid 25 kvitnia 2018 r. № 410 zakon.rada.gov.ua Retrieved from https://zakon.rada.gov. ua/laws/show/410-2018-\%D0\%BF\#n52

8. Derzhavne upravlinnia okhoronoiu zdorovia v Ukraini: heneza i perspektyvy rozvytku : kol. monohr. / kol. avt. ; uporiad. prof. Ya.F. Radysh, peredm. T. D. Bakhteievoi ; za zah. red. prof. M. M. Bilynskoi, prof. Ya.F. Radysha. K.: NADU, 2013. 424 s. academy.gov.ua Retrieved from http:// academy.gov.ua/NMKD/library_nadu/Monografiy/aa2d8d7f-9def-4f49-a86b43c3db9dbd31.pdf

9. Detsentralizatsiia. Sektor medytsyna decentralization.gov.ua Retrieved from https://decentralization.gov.ua/health

10. Dialohichna model zmin. Instytut kolektyvnoho liderstva. collectiveleadership.de Retrieved from https://www.collectiveleadership.de/ blog/article/the-dialogic-change-model/

11. Hladun O.M. Narysy z demohrafichnoi istorii Ukrainy KhKh stolittia : monohrafiia; NAN Ukrainy, In-t demohraf. ta sotsialn. doslidzh. im. M.V. Ptukhy. Kyiv, 2018. 224 s. idss.org.ua Retrieved from https://idss.org.ua/ monografii/Gl.pdf 
12. Holova Natsionalnoi sluzhby zdorovia Oleh Petrenko: «Iakshcho chesno, zaraz realizuietsia superoptymistychnyi stsenarii reformy» ukr. lb.ua Retrieved from https://ukr.lb.ua/society/2018/11/07/411769_golova natsionalnoi sluzhbi zdorovya.html

13. INSTRUKTSII nszu.gov.ua Retrieved from https://nszu.gov. ua/ogoloshennya-pro-ukladennya-dogovoriv/dlya-medichnih-zakladiv/ instrukciyi

14. Kniazevych V. M. Rozvytok natsionalnoi systemy okhorony zdorovia: stan, perspektyvy ta shliakhy rozbudovy Okhorona zdorovia Ukrainy. 2008. № $3(31)$. - S. 5.

15. Konstytutsiia Ukrainy: Zakon Ukrainy vid 28.06.1996 № 254k/96VR zakon.rada.gov.ua Retrieved from https://zakon.rada.gov.ua/laws/ show/254\%D0\%BA/96-\%D0\%B2\%D1\%80\# n4324

16. Korolchuk O. L. Dynamika smertnosti v Ukraini: vymoha zavershennia transformatsii systemy okhorony zdorovia. Investytsii: praktyka ta dosvid. 2015.№ 18. S. 115-120. www.investplan.com.ua Retrieved from http://www. investplan.com.ua/pdf/18_2015/27.pdf

17. Kostiuk V.S. Reformuvannia okhorony zdorovia v Ukraini v umovakh yevropeiskoi oriientatsii. Naukovyi visnyk Mizhnarodnoho humanitarnoho universytetu. 2017. Vyp. 24(2). S. 39-43 www.vestnikeconom.mgu.od.ua Retrieved from http://www.vestnik-econom.mgu.od.ua/ journal/2017/24-2-2017/11.pdf

18. Lytvynenko M. V. Pryntsypy natsionalnoi systemy okhorony zdorovia v Ukraini. Teoriia ta praktyka derzhavnoho upravlinnia. 2015. Vyp. 2 (49). S.18. www.kbuapa.kharkov.ua Retrieved from http://www.kbuapa.kharkov.ua/ebook/tpdu/2015-2/doc/2/12.pdf

19. Metodychni rekomendatsii z pytan peretvorennia zakladiv okhorony zdorovia $\mathrm{z}$ biudzhetnykh ustanov na komunalni nekomertsiini pidpryiemstva moz.gov.ua Retrieved from https://moz.gov.ua/article/news/metodichnirekomendacii-z-pitan-peretvorennja-zakladiv-ohoroni-zdorovja-z-bjudzhetnihustanov-na-komunalni-nekomercijni-pidpriemstva

20. Ministerstvo okhorony zdorovia Ukrainy moz.gov.ua Retrieved from https://moz.gov.ua

21. Ministerstvo zdorovia Ukrainy moz.gov.ua Retrieved from https://moz. gov.ua/ 
22. MOZ poinformuvalo parlamentskyi Komitet z pytan okhorony zdorovia pro pidhotovku do startu reform na pervyntsi ta formuvannia hospitalnykh okruhiv moz.gov.ua Retrieved from https://moz.gov.ua/article/news/moz-poinformuvaloparlamentskij-komitet-z-pitan-ohoroni-zdorov\%e2\%80\%99ja-pro-pidgotovkudo-startu-reform-na-pervinci-ta-formuvannja-gospitalnih-okrugiv

23. MOZ pokazalo detalnu prezentatsiiu pro reformu systemy okhorony zdorovia tyzhden.ua Retrieved from https://tyzhden.ua/News/179746

24. MOZ prezentuvalo hromadskosti zminy, yaki chekaiut medychnu haluz v 2017 rotsi moz.gov.ua Retrieved from https://moz.gov.ua/article/news/mozprezentuvalo-gromadskosti-zmini-jaki-chekajut-medichnu-galuz-v-2017-roci

25. Natsionalna sluzhba zdorovia Ukrainy nszu.gov.ua Retrieved from https://nszu.gov.ua/

26. Natsionalna sluzhba zdorovia Ukrainy www.facebook.com Retrieved from https://www.facebook.com/nszu.ukr/

27. Perelik normatyvno pravovykh aktiv $\mathrm{z}$ reformuvannia systemy okhorony zdorovia moz.gov.ua Retrieved from https://moz.gov.ua/plan-reform

28. Premier-ministr Volodymyr Hroisman, MOZ Ukrainy ta Natssluzhba zdorovia prezentuvaly plan transformatsii medychnoi systemy na 2019 rik moz.gov.ua Retrieved from https://moz.gov.ua/article/news/premer-ministrvolodimir-grojsman-moz-ukraini-ta-nacsluzhba-zdorov\%e2\%80\%99japrezentuvali-plan-transformacii-medichnoi-sistemi-na-2019-rik

29. PRES-SLUZHBA nszu.gov.ua Retrieved from https://nszu.gov.ua/pronszu/pres-sluzhba

30. Pro skhvalennia Kontseptsii reformy finansuvannia systemy okhorony zdorovia: rozporiadzhennia Kabinetu Ministriv Ukrainy vid 30 lystopada 2016 r. № 1013-r moz.gov.ua Retrieved from https://zakon2.rada.gov.ua/laws/ show/1013-2016-\%D1\%80/paran8

31. Pro vprovadzhennia reformy systemy hromadskoho zdorovia - narada z rehionamy moz.gov.ua Retrieved from https://moz.gov.ua/article/news/provprovadzhennja-reformi-sistemi-gromadskogo-zdorovja-\%e2\%80\%93-naradaz-regionami

32. Proekt z pidtrymky reformy PMD healthreform.in.ua Retrieved from https://healthreform.in.ua/about/

33. Prohrama dlia Ukrainy $\mathrm{z}$ rozshyrennia prav i mozhlyvostei na mistsevomu rivni, pidzvitnosti ta rozvytku «U-LEAD z Yevropoiu» donors. 
decentralization.gov.ua Retrieved from https://donors.decentralization.gov.ua/ project/u-lead/

34. Reforma systemy okhorony zdorovia ta vyvedennia ukrainskoi medytsyny na yevropeiskyi riven - odyn iz priorytetiv diialnosti Uriadu moz.gov. ua Retrieved from https://moz.gov.ua/article/news/reforma-sistemi-ohoronizdorov\%e2\%80\%99ja-ta-vivedennja-ukrainskoi-medicini-na-evropejskijriven-\%e2\%80\%93-odin-iz-prioritetiv-dijalnosti-urjadu

35. Reformy v Ukraini: prohres u 2017, priorytety na 2018 barcelona.mfa. gov.ua Retrieved from https://barcelona.mfa.gov.ua/news/63415-reforms-inukraine-progress-in-2017-priorities-for-2018

36. Sherstiuk N.S. Sokolov A.V. Zdorovia naselennia Ukrainy ta yoho vplyv na demohrafichnu sytuatsiiu. Ekonomika i suspilstvo. 2016. Vyp.5. S.316-319. www.economyandsociety.in.ua Retrieved from http://www.economyandsociety. in.ua/journal/5_ukr/57.pdf

37. Spivvidnoshennia naiavnoho naselennia ta pidpysanykh deklaratsii nszu.gov.ua Retrieved from https://nszu.gov.ua/gromadyanam/elektronnakarta-misc-nadannya-pmd

38. Storinka Facebook «Natsionalna sluzhba zdorovia Ukrainy» www. facebook.com Retrieved from https://www.facebook.com/nszu.ukr/

39. Suprun Uliana. Zminyty medytsynu, shchob vyzhyty. Ukrainska pravda life.pravda.com.ua Retrieved from https:/life.pravda.com.ua/ columns/2016/07/13/215192/

40. Trahediia, yakoi mozhna unyknuty. Podolannia v Ukraini kryzy zdorovia liudyny. Dosvid Yevropy: zvit / pidhot. Rekkha Menon [ta in.]. K.: Verso-04, 2009. $72 \mathrm{~s}$.

41. Tsiborovskyi O.M.Zdorovia naselennia i faktory ryzyku, shcho vplyvaiut na yoho stan, yak obiekt upravlinnia (ohliad literatury). Ukraina. Zdorovia natsii. 2015. № 2. S. 13-19. www.irbis-nbuv.gov.ua Retrieved from http:// www.irbis-nbuv.gov.ua/cgi-in/irbis_nbuv/cgiirbis_64.exe?C21COM=2\&I21D $\mathrm{BN}=\mathrm{UJRN} \& \mathrm{P} 21 \mathrm{DBN}=\mathrm{UJRN} \& \mathrm{IMAGE}$ _FILE_DOWNLOAD=1\&Image_file name $=$ PDF/Uzn_2015_2_4.pdf

42. Ukraina poinformuvala YeS pro vprovadzhennia systemnykh haluzevykh reform okhorony zdorovia moz.gov.ua Retrieved from https://moz. gov.ua/article/news/ukraina-poinformuvala-es-pro-vprovadzhennja-sistemnihgaluzevih-reform-ohoroni-zdorovja 
43. Zvit Natsionalnoi sluzhby zdorovia Ukrainy 2018 Retrieved from https://nszu.gov.ua/storage/files/zvit-2018.pdf

44. Zvit Natsionalnoi sluzhby zdorovia Ukrainy 4 kvartal nszu.gov.ua Retrieved from https://nszu.gov.ua/storage/files/4-qrtl-report-2019.pdf

\section{Відомості про авторів / Information about the Authors}

Дзвінчук Дмитро Іванович: Івано-Франківський національний технічний університет нафти і газу: вул. Карпатська 15, м. Івано-Франківськ, 76019, Україна.

Dmytro Dzvinchuk: Ivano-Frankivsk National Technical University of Oil and Gas, str.15, Karpatska Ivano-Frankivsk, 76019, Ukraine.

\section{ORCID. ORG/0000-0002-6391-3822}

\section{E-mail: dzvin56@ukr.net}

Баран Марія Петрівна: Івано-Франківський національний технічний університет нафти і газу: вул. Карпатська 15, м. Івано-Франківськ, 76019, Україна.

Mariia Baran: Ivano-Frankivsk National Technical University of Oil and Gas, str.13, Korolia Danyla, Ivano-Frankivsk, 76019, Ukraine.

ORCID. ORG/0000-0001-6070-9378

E-mail: m_baran2014@hotmail.com 